\title{
OPTIMALISASI SALURAN PEMBUANG TO’ PONGO DESA TO’ PONGO KECAMATAN LAMASI
}

\author{
Andi Kartini Sari ${ }^{1)}$ \\ 1) Dosen Program Studi Teknik Sipil, Universitas Andi Djemma, Palopo \\ 1)tin_sary@unanda.ac.id
}

\begin{abstract}
Abstrak
Penelitan ini bertujuan untuk mengetahui dampak optimalisasi pada saluran pembuang To'pongo dan seberapa besar daya tampung volume genangan serta debit rata-rata dan debit rencana pada saluran tersebut untuk para petani Desa To'pongo. Lokasi penelitian berada di Desa To' Pongo Kecamatan Lamasi Kabupaten Luwu. Perhitungan volume saluran pembuang eksisting diambil satu sempel penampang patok saja, dengan Lebar saluran (B) 1,92 m, lebar saluran (B1) 1,20 m dan tinggi saluran (T) 0,63 m. Lebar atas genangan (B) 0,57 cm, lebar bawah genangan (B1) 0,40 cm, tinggi genangan (T) $0.40 \mathrm{~cm}$, panjang tersier $\left(\mathrm{P}_{1}\right) 488 \mathrm{~m}$ dan Panjang tarsier $\left(\mathrm{P}_{2}\right) 451 \mathrm{~m}$. Hasil perhitungan didapatkan panjang saluran pembuang To'Pongo $2236 \mathrm{~m}$, volume eksisting pembuang To'pongo $3939.71 \mathrm{~m}^{3}$, Volume rencana $5781.33 \mathrm{~m}^{3}$, volume luapan areal sawah $406,187 \mathrm{~m}^{3}$, dan volume saluran tersier bernilai $187,31 \mathrm{~m}^{3}$, Sehingga berdasarkan hasil tersebut dapat di nyatakan pengoptimalan pada saluran pembuang To'Pongo dengan jumlah volume luapan pada areal sawah $406,187 \mathrm{~m}^{3}$, sedangkan volume rencana optimalisasi adalah $9720,95 \mathrm{~m}^{3}$. Dengan hasil optimalisasi yang maksimal tentu kecepatan aliran luapan di areal sawah akan semakin maksimal.
\end{abstract}

Kata Kunci: Optimalisasi, Saluran pembuang, volume, debit

\section{PENDAHULUAN}

Air adalah salah satu zat yang penting bagi semua makhluk hidup di muka bumi. Wujudnya bisa berupa cairan es (padat) dan uap/ gas. Bisa dikatakan, karena air maka Bumi menjadi satu-satunya planet dalam tata surya kita yang memiliki kehidupan (Parker 2017).

Pengelolahan air yang salah dapat menjadi bencana bagi kehidupan kita. Air yang berlebihan di suatu tempat akibat hujan yang besar dan genangan menimbulkan kerugian yang sangat besar bagi para petani. Hal ini bisa terjadi karena diakibatkan oleh aula manusia itu sendiri. Salah satunya adalah tidak terjaganya prasarana yang sudah disiapkan baik dari pemerintah mauapun masyarakat itu yang membuang sampah sembarang, selain itu juga karena tingginta curah hujan uang turun pada daerah tersebut. Berdasarkan hal di atas, hamper semua daerah di Indonesia sering mengalami genangan air disebabkan terjadinya pendangkalan baik pada sungai maupun saluran pembuang. Oleh karena itu diperlukan optimalisasi pada saluran tersebut.

Data penelitian ini meliputi tentang saluran pembuang yang mengakibatkan banjir di desa To'pongo kecamatan Lamasi. Kondisi Sistem saluran pembuang To'Pongo direncanakan untuk mengalirkan kelebihan air secara gravitasi. Pembuangan kelebihan air dengan pompa biasanya tidak layak dari segi ekonomi. Daerah irigasi Desa To'Pongo dilengkapi dengan bangunan-bangunan pengendali banjir disepanjang sungai untuk mencegah masuknya air banjir kedalam sawah irigasi. Kriteria perencanaan ini membahas jaringan pembuang To'Pongo yang sangat membutuhkan optimalisasi pada saluran pembuang, karena air sawah yang sudah tidak terpakai sudah melewati batas kebutuhan tanaman padi sehingga dampak yang terjadi sangat merugikan khusunya pada masyarakat karena terancam gagal panen. Hasil perhitungan volume saluran eksisting didapatkan analisa dimensi saluran dilakukan untuk mendapatkan volume kapasitas saluran pembuang 
eksisting, yang nantinya akan di bandingkan dengan volume rencana sehingga dapat di ketahui apakah saluran tersebut mampu menampung volume optimalisasi rencana.

\section{METODOLOGI PENELITIAN}

Penelitian ini dilaksanakan di Desa To' Pongo Kecamatan Lamasi Kabupaten Luwu. Saluran pembuangan di desa ini pada tahun 2017 menimbulkan dampak yang begitu besar diantaranya meluapnya air yang diakibatkan tidak optimalnya saluran pembuang. Selain banjir juga sangat mempengaruhi para petani khususnya petani padi. Oleh sebab itu, penelitian ini tentang optimalisai saluran pembuang yang mengakibatkan banjir di desa To'pongo kecamatan Lamas. berikut:

Beberapa istilah dan variabel yang digunakan dalam penulisan adalah sebagai

\section{Saluran Pembuang}

Perencanaan saluran pembuang harus memberikan pemecahan dengan biaya pelaksanaan dan pemeliharaan yang terendah. Ruas-ruas saluran harus stabil terhadap erosi dan sendimentasi minimal pada setiap potongan melintang dan seimbang. Dengan adanya pembuang air persawahan lebih bersih dari sedimen.

\section{Lumpur}

Lumpur adalah campuran cair atau semi cair antara air dan tanah . Lumpur terjadi saat tanah basah akibat genangan air dan campuran partikel endapan lumpur dan tanah liat yang menyatu lama kelamaan akan mengeras menimbulkan sendimentasi pada sebuah ruang genangan. Sehingga dapat menimbulkan dampak negatif dan berdampak buruk pada pemukiman, perkebunan, pertanian dan daerah-daerah lainya.

\section{Genangan}

Genangan adalah peristiwa manakala kawasan dipenuhi air karena tidak ada draenase yang memutus air tersebut keluar kawasan (Sabirin, 2017). Jadi genangan berhubungan erat dengan resapan dan saluran drainase. Genangan berasal dari kata "genang" yang artinya berhenti mengalir. Sehingga pengertian genangan ini adalah air yang berhenti mengalir pada suatu area tertentu yang merupakan bukan badan air atau tempat air. Namun demikian bagi masyarakat secara umum, baik genangan maupun banjir disamakan istilahnya sebagai banjir.

\section{Jaringan Pembuang}

Pada umumnya jaringan pembuang direncanakan untuk mengalirkan kelebihan air secara gravitasi. Pembuangan kelebihan air dengan pompa biasanya tidak layak dari segi ekonomi. Kriteria perencanaan ini membahas jaringan pembuang yang cocok untuk membuang kelebihan air sawah dan air irigasi yang masuk melebihi dari kebutuhan air pada areal persawahan sekaligus jumla curah hujan yang tinggi yang sulit di prekdisi akibat musim yang berubah-ubah, optimalisasi ini sangat penting untuk menangulangi banyaknya jumlah genangan air yang terjadi akibat mengecilnya dimensi saluran pembuang disebabkan karenan adanya pengendapan lumpur sehingga jumlah volume penampang saluran pembuang tidak mampu menampung jumlah genangan yang masuk ke saluran pembuang sehingga menyebabkan banjir dan mengenangannya air pada areal persawahan.

\section{Banjir}

Air dari saluran pembuang mempunyai pengaruh negatife pada muka air tanah atau pada air yang masuk dari laut dan sebagainya. Oleh karena itu perencana harus mempertimbangkan faktor tersebut dengan hati-hati guna memperkecil dampak yang mungkin timbul. 


\section{Optimalisasi}

Optimalisasi berasal dari kata optimal yang artinya terbaik atau tertinggi, sedangkan optimalisasi adalah proses menjadikan sesuatu menjadi baik. Menurut Winardi(1999), optimalisasi adalah ukuran yang menyebabkan tercapainya tujuan sedangkan jika dipandang dari sudut usaha, usaha memaksimalkan kegiatan sehingga mewujudkan keuntungan yang diinginkan. Jadi optimalisasi saluran pembuang adalah proses yang dilakukan untuk menormalkan atau memperbaiki saluran pembuang yang mengalami pendangkalan akibat sedimentasi.

\section{Desain penampang galian}

Desain penampang galian harus direncanakan terlebih dahulu dan diperhitungkan berapa besar volume yang perlu digali untuk mengoptimalkan saluran serta pengambilan data ekisting langsung di lokasi.

\section{Curah Hujan}

Curah hujan merupakan ketinggian air hujan yang terkumpul dalam tempat yang datar, tidak menguap, tidak meresap, dan tidak mengalir. Curah hujan satu milimeter artinya dalam luasan satu meter persegi pada tempat yang datar tertampung air setinggi satu milimeter atau tertampung air sebanyak satu liter. Intensitas hujan adalah banyaknya curah hujan persatuan jangka waktu tertentu. Apabila dikatakan intensitasnya besar berarti hujan lebat dan kondisi ini sangat berbahaya karena berdampak dapat menimbulkan banjir, longsor dan efek negatif terhadap tanaman.

\section{Debit Air}

Menurut Hamalin(2015), debit air adalah jumlah air yang mengalir dari suatu penampang tertentu (sungai/saluran/mata air), persatuan waktu.

\section{HASIL DAN PEMBAHASAN \\ Kondisi Sistem Saluran Pembuang To'Pongo}

Saluran pembuang To'Pongo direncanakan untuk mengalirkan kelebihan air secara gravitasi. Pembuangan kelebihan air dengan pompa biasanya tidak layak dari segi ekonomi. Daerah-daerah irigasi Desa To'Pongo dilengkapi dengan bangunan-bangunan pengendali banjir disepanjang sungai untuk mencegah masuknya air banjir kedalam sawah-sawah irigasi. Kriteria perencanaan ini membahas jaringan pembuang To'Pongo Desa To'pongo Kecamatan Lamasi yang sangat membutuhkan optimalisasi pada saluran pembuang, karena air sawah yang sudah tidak terpakai sudah melewati batas kebutuhan tanaman padi sehingga dampak yang terjadi sangat merugikan khusunya pada masyarakat karena terancam gagal panen.

\section{Perhitungan Volume Saluran Eksisting}

Analisa dimensi saluran dilakukan untuk mendapatkan volume kapasitas saluran pembuang eksisting, yang nantinya akan di bandingkan dengan volume rencana sehingga dapat di ketahui apakah saluran tersebut mampu menampung volume optimalisasi rencana. Dalam perhitungan volume saluran pembuang eksisting di ambil satu sempel saja yakni penampang patok 0 saja, karna cara menghitungnya sama perpenampang yang lain tinggal di kali dengan panjang saluran pembuang. 


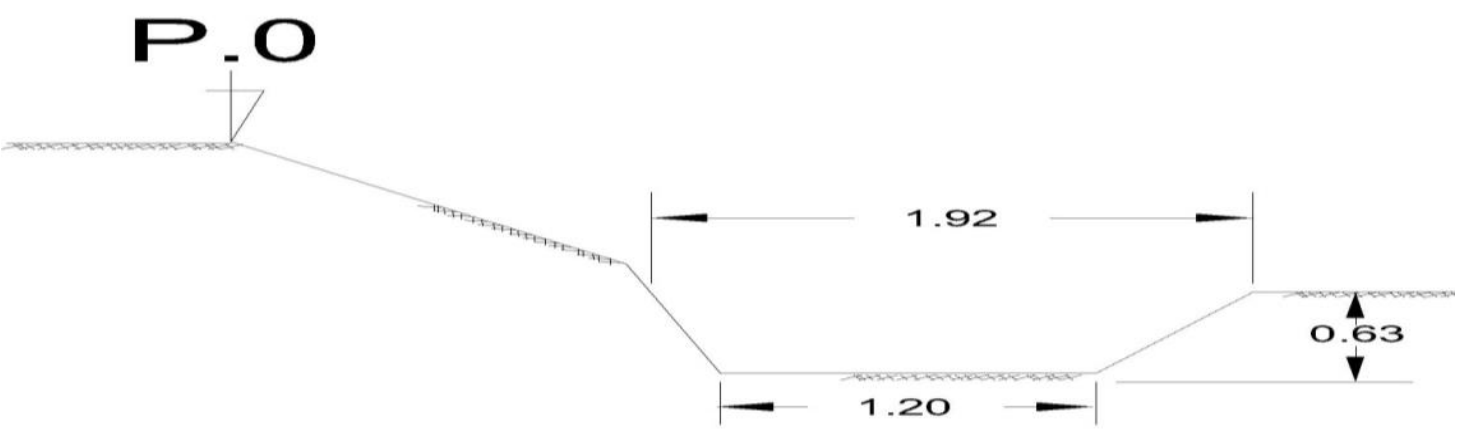

Gambar 1. Volume Saluran Eksisting

Dimensi saluran pembuang To'Pongo eksisting patok 0. Diketahui lebar saluran (B) $=1.92 \mathrm{~m}$, lebar saluran $(\mathrm{B} 1)=1.20 \mathrm{~m}$, tinggi saluran $(\mathrm{T})=0.63 \mathrm{~m}$ $V=\frac{B+B 1}{2}+\mathrm{T}$

Didapatkan $\mathrm{V}=0.98 \mathrm{~m}^{3}$

\section{Perhitungan Volume Rencana}

Perhitungan volume rencana dilakukan dengan cara yang sama dengan cara perhitungan volume eksisting. Dalam perhitungan volume saluran to' pongo di ambil satu sampel saja. Karena semua penampang galian saluran sama yang membadakanya hanyalah kedalaman galian karena endapan lumpur pada saluran.

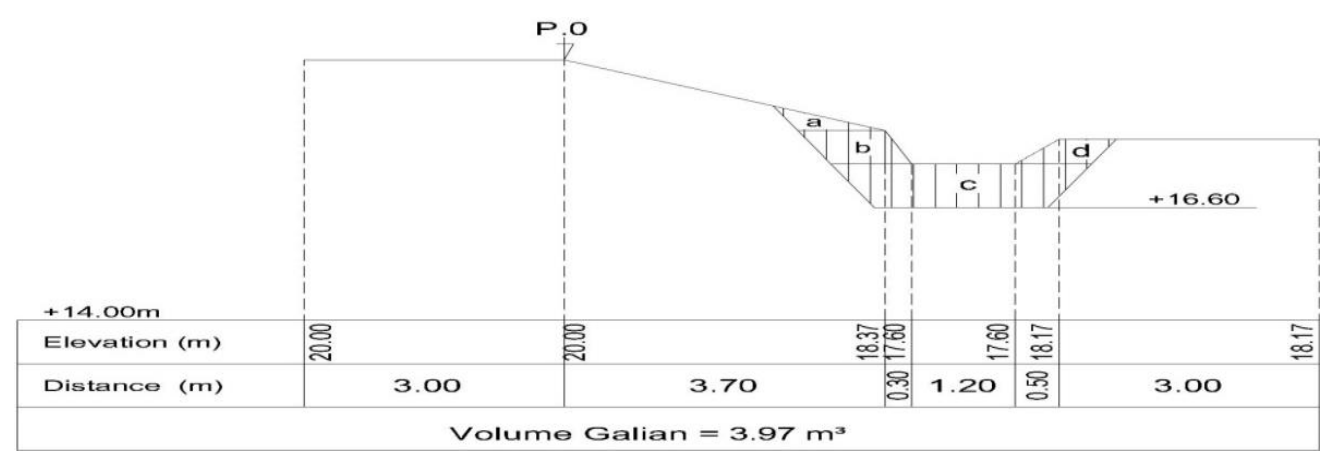

Gambar 2. Perhitungan Volume Rencana

Dengan menggunakan persamaan $1 \mathrm{di}$ atas,maka di dapatkan nilai a=0,28 $\mathrm{m}^{3}, \mathrm{~b}=0,75$ $\mathrm{m}^{3}, \mathrm{c}=0,436 \mathrm{~m}^{3}$, karena $\mathrm{A}=\mathrm{a}+\mathrm{b}+\mathrm{c}$ didapatkan $\mathrm{A}=3,97 \mathrm{~m}^{3}$

Perhitungan Volume Galian Dan Eksisting

Tabel 1. Volume Galian Dan Eksisting

\begin{tabular}{|c|c|c|c|c|c|}
\hline No. Ptk & $\begin{array}{c}\text { Luas } \\
\left(\mathbf{m}^{2}\right)\end{array}$ & $\begin{array}{c}\text { Luas Rata-Rata } \\
\qquad\left(\mathbf{m}^{2}\right)\end{array}$ & Jarak & $\begin{array}{c}\text { Volume } \\
\left(\mathbf{m}^{3}\right)\end{array}$ & Ket. \\
\hline \multirow[t]{2}{*}{ P.0 } & 0.98 & & & & \\
\hline & & 0.895 & 60.00 & 53.70 & \\
\hline \multirow[t]{2}{*}{ P.1 } & 0.81 & & & & \\
\hline & & 0.64 & 66.00 & 42.24 & \\
\hline \multirow[t]{2}{*}{ P.2 } & 0.47 & & & & \\
\hline & & 1.39 & 72.00 & 100.08 & \\
\hline \multirow[t]{2}{*}{ P. 3} & 2.31 & & & & \\
\hline & & 1.43 & 72.00 & 102.96 & \\
\hline \multirow[t]{2}{*}{ P.4 } & 0.55 & & & & \\
\hline & & 0.445 & 94.00 & 41.83 & \\
\hline
\end{tabular}




\begin{tabular}{|c|c|c|c|c|}
\hline & & 0.35 & 46.00 & 16.10 \\
\hline \multirow[t]{2}{*}{ P.6 } & 0.36 & & & \\
\hline & & 0.44 & 54.00 & 23.76 \\
\hline \multirow[t]{2}{*}{ P.7 } & 0.52 & & & \\
\hline & & 0.61 & 70.00 & 42.70 \\
\hline \multirow[t]{2}{*}{ P.8 } & 0.70 & & & \\
\hline & & 0.84 & 41.00 & 34.44 \\
\hline \multirow[t]{2}{*}{ P.9 } & 0.98 & & & \\
\hline & & 1.615 & 68.00 & 109.82 \\
\hline \multirow{2}{*}{ P.10 } & 2.25 & & & \\
\hline & & 2.755 & 68.00 & 187.34 \\
\hline \multirow{2}{*}{ P.11 } & 3.26 & & & \\
\hline & & 2.71 & 84.00 & 227.64 \\
\hline \multirow[t]{2}{*}{ P.12 } & 2.16 & & & \\
\hline & & 1.63 & 60.00 & 97.80 \\
\hline \multirow[t]{2}{*}{ P.13 } & 1.10 & & & \\
\hline & & 1.065 & 60.00 & 63.90 \\
\hline \multirow[t]{2}{*}{ P.14 } & 1.03 & & & \\
\hline & & 1.405 & 85.00 & 119.43 \\
\hline \multirow[t]{2}{*}{ P.15 } & 1.78 & & & \\
\hline & & 1.66 & 80.00 & 132.80 \\
\hline \multirow[t]{2}{*}{ P.16 } & 1.54 & & & \\
\hline & & 1.395 & 60.00 & 83.70 \\
\hline \multirow[t]{2}{*}{ P.17 } & 1.25 & & & \\
\hline & & 1.38 & 30.00 & 41.40 \\
\hline \multirow[t]{2}{*}{ P.18 } & 1.51 & & & \\
\hline & & 1.55 & 46.00 & 71.30 \\
\hline \multirow[t]{2}{*}{ P.19 } & 1.59 & & & \\
\hline & & 2.185 & 41.00 & 89.59 \\
\hline \multirow[t]{2}{*}{ P.20 } & 2.78 & & & \\
\hline & & 2.62 & 97.00 & 254.14 \\
\hline \multirow[t]{2}{*}{ P.21 } & 2.46 & & & \\
\hline & & 2.235 & 29.00 & 64.82 \\
\hline \multirow[t]{2}{*}{ P.22 } & 2.01 & & & \\
\hline & & 3.105 & 49.00 & 152.15 \\
\hline \multirow[t]{2}{*}{ P.23 } & 4.20 & & & \\
\hline & & 3.755 & 58.00 & 217.79 \\
\hline \multirow[t]{2}{*}{ P.24 } & 3.31 & & & \\
\hline & & 2.765 & 52.00 & 143.78 \\
\hline P.25 & 2.22 & & & \\
\hline & & 2.01 & 80.00 & 160.80 \\
\hline P.26 & 1.80 & & & \\
\hline & & 1.85 & 50.00 & 92.50 \\
\hline P.27 & 1.90 & & & \\
\hline & & 1.8 & 50.00 & 90.00 \\
\hline P.28 & 1.70 & & & \\
\hline & & 1.865 & 41.00 & 76.47 \\
\hline P.29 & 2.03 & & & \\
\hline & & 2.075 & 50.00 & 103.75 \\
\hline P.30 & 2.12 & & & \\
\hline & & 2.185 & 50.00 & 109.25 \\
\hline P.31 & 2.25 & & & \\
\hline & & 2.19 & 50.00 & 109.50 \\
\hline P.32 & 2.13 & & & \\
\hline & & 2.195 & 50.00 & 109.75 \\
\hline
\end{tabular}




\begin{tabular}{|c|c|c|c|c|}
\hline & & 2.22 & 50.00 & 111.00 \\
\hline \multirow[t]{2}{*}{ P.34 } & 2.18 & & & \\
\hline & & 2.165 & 50.00 & 108.25 \\
\hline \multirow[t]{2}{*}{ P.35 } & 2.15 & & & \\
\hline & & 2.115 & 50.00 & 105.75 \\
\hline \multirow[t]{2}{*}{ P.36 } & 2.08 & & & \\
\hline & & 2.03 & 50.00 & 101.50 \\
\hline \multirow[t]{2}{*}{ P.37 } & 1.98 & & & \\
\hline & & 2 & 73.00 & 146.00 \\
\hline \multirow[t]{2}{*}{ P.38 } & 2.02 & & & \\
\hline & JUMLAH & & $2,236.00$ & 3,939.71 \\
\hline
\end{tabular}

\section{Perhitungan Volume Genangan Air Saluran Tersier}

Perhitungan volume genangan dilakukan untuk mengetahui jumlah genangan pada saat banjir. Dalam menghitung volume genangan yang diketahui nantinya akan di tambahkan dengan volume genangan pada area sawah untuk mengetahui jumlah genangan air yang tidak terpakai dan terbuang ke saluran pembunag To'Pongo.

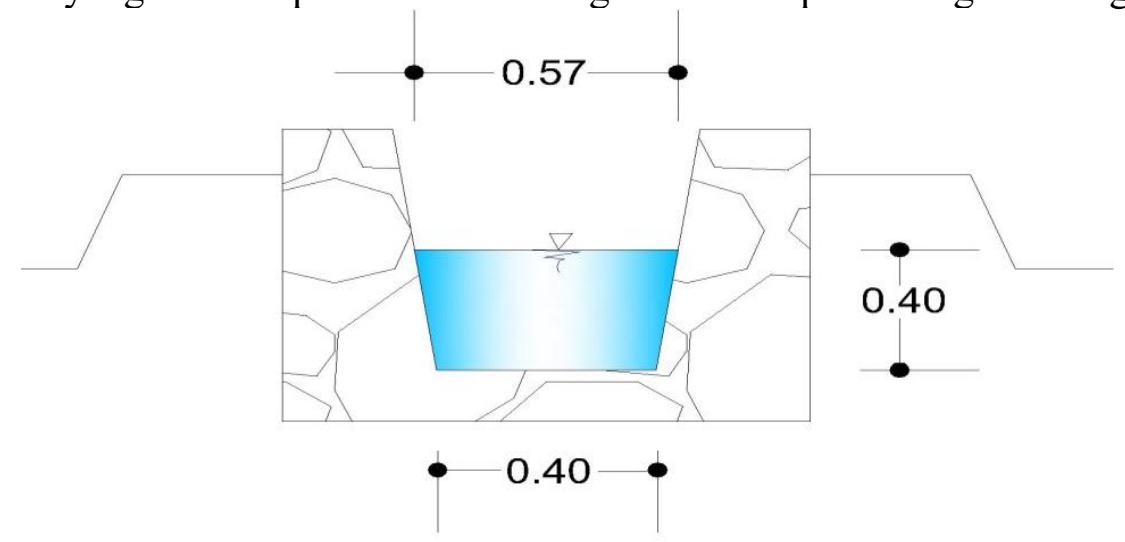

Gambar 3. Volume Genangan Air Saluran Tersier

Diketahui lebar atas genangan $(B)=0.57 \mathrm{~cm}$, lebar bawah genangan $(B 1)=0.40 \mathrm{~cm}$, tinggi genangan $(\mathrm{T})=0.40 \mathrm{~cm}$, panjang tersier $1(\mathrm{P})=488 \mathrm{~m}$, dan panjang tarsier $2(\mathrm{P} 1)$ $=451 \mathrm{~m}$, dengan menggunakan persamaan,

$V=\frac{\mathrm{B}+\mathrm{B} 1}{2} \times \mathrm{T} \times \mathrm{P}_{\mathrm{n}}$

Maka didapatkan volume saluran tersier 1 adalah $97,72 \mathrm{~m}^{3}$, dan saluran tersier 2 adalah $89,59 \mathrm{~m}^{3}$. Dengan demikian, total volume genangan saluran tersier adalah $187,31 \mathrm{~m}^{3}$.

\section{Perhitungan Luapan Areal Sawah}

Perhitungan areal sawah diukur dengan mengunakan bantuan GPS dengan metode polygon tertutup . Dalam perhitungan ini data yang di ambil hanya di daerah saluran pembuang To'pongo .Karena daerah tersebut yang mengalami luapan. Dari perhitungan yang dilakukan didapatkan luas area persawahan(a) adalah $580.000 \mathrm{~m}^{2}$, dan tinggi genangan sawah(b) adalah $0,70 \mathrm{~m}$, dengan volume genangan saluran tersier(c) yang didapat sebesar $187,31 \mathrm{~m}^{3}$, maka:

$\mathrm{V}=a \times b+c$

maka total seluruh volume genangan saluran tersier adalah $406.000 \mathrm{~m}^{3}$. 


\section{Perhitungan Debit}

Perhitungan debit di lakukan untuk mengetahui debit ekisting dan debit rencana pada saluran pembuang To'pongo. Perhitungan di lakukan di tiga titik saja karena kondisi saluran pembuang To'pongo yang cenderung berkelok (meander), sehinga variasi tinggi air dengan debit yang berubah-ubah jadi pemgambilan sampel hanya di tiga titik saja.

$Q=\frac{\text { waktu aliran }}{\text { Volume aliran }}$

Dengan menggunakan persamaan (4) di atas,dengan $\mathrm{Q}$ adalah debit eksisting maka diperoleh :

a) Debit eksisting (P.0)

Luas penampang P.0 (A1)=0,98 $\mathrm{m}^{2}$, waktu aliran $(\mathrm{V} 1)=21 \operatorname{detik}, \operatorname{jarak}(\mathrm{J} 1)=5 \mathrm{~m}$, dan volume aliran(B1) $=0,98 \times 5=4,9 \mathrm{~m}^{3}$, maka debitnya sebesar $4,28 \mathrm{~m}^{3} /$ detik

b) Debit eksisting (P.20)

Luas penampang P.20 (A1) $=2,78 \mathrm{~m}^{2}$, waktu aliran $(\mathrm{V} 1)=18$ detik, jarak $(\mathrm{J} 1)=5 \mathrm{~m}$, dan volume aliran $(\mathrm{B} 1)=2,78 \times 5=13,9 \mathrm{~m}^{3}$, maka debitnya sebesar $1,29 \mathrm{~m}^{3} /$ detik.

c) Debit eksisting (P.38)

Luas penampang P.38 $(\mathrm{A} 1)=2,02 \mathrm{~m}^{2}$, waktu aliran $(\mathrm{V} 1)=6$ detik, jarak $(\mathrm{J} 1)=5 \mathrm{~m}$, dan volume aliran $(\mathrm{B} 1)=2,02 \times 5=10,1 \mathrm{~m}^{3}$, maka debitnya sebesar $0,59 \mathrm{~m}^{3} /$ detik.

d) Perhitungan debit rencana (P.0)

Luas penampang P.0 (A1)=4,39 $\mathrm{m}^{2}$, waktu aliran $(\mathrm{V} 1)=7 \operatorname{detik}, \operatorname{jarak}(\mathrm{J} 1)=5 \mathrm{~m}$, dan volume aliran(B1) $=4,39 \times 5=21,35 \mathrm{~m}^{3}$, maka debitnya sebesar $0.32 \mathrm{~m}^{3} /$ detik

e) Perhitungan debit rencana (P.20)

Luas penampang P.0 (A1) $=5,31 \mathrm{~m}^{2}$, waktu aliran $(\mathrm{V} 1)=8$ detik, jarak $(\mathrm{J} 1)=5 \mathrm{~m}$, dan volume aliran(B1) $=5,31 \times 5=26,55 \mathrm{~m}^{3}$, maka debitnya sebesar $0.30 \mathrm{~m}^{3} /$ detik

f) Perhitungan debit rencana (P.38)

Luas penampang P.0 $(\mathrm{A} 1)=3,48 \mathrm{~m}^{2}$, waktu aliran $(\mathrm{V} 1)=10$ detik, $\operatorname{jarak}(\mathrm{J} 1)=5 \mathrm{~m}$, dan volume aliran(B1) $=3,48 \times 5=14,4 \mathrm{~m}^{3}$, maka debitnya sebesar $0.34 \mathrm{~m}^{3} /$ detik

Dari hasil perhitungan di tiga titik saluran pembuang To'pongo terjadi selisih waktu aliran sehingga berpengaruh pada debit. Pengukuran waktu aliran dilakukan pada saat permukaan saluran penuh, perhitungan dibagi menjadi tiga titik dengan jarak 5 meter per titik yaitu P.0, P.20, P.38 masing-masing titik memiliki waktu aliran dan debit tersendiri.

Tabel 2. Debit Eksisting dan Rencana

\begin{tabular}{|c|c|c|c|}
\hline \multirow[b]{3}{*}{ P.0 } & \multicolumn{2}{|c|}{ Debit(m³/detik) } & \multirow[t]{3}{*}{ Ket. } \\
\hline & Eksisting & Rencana & \\
\hline & 4,28 & 0,32 & \\
\hline P.20 & 1,29 & 0,3 & \\
\hline P.38 & 0,59 & 0,32 & \\
\hline Rata-rata & 2,05 & 0,32 & \\
\hline
\end{tabular}

\section{Pembahasan}

Daerah yang diteliti pada pengerjaan tugas akhir ini adalah saluran pembuang To'Pongo Desa To'Pongo Kecamatan Lamasi. Berdasarkan survey yang dilakukan langsung ke lokasi ini. Kondisi saluran pembuang yang sudah ada memang sudah tidak memadai lagi. hal ini di sebabkan oleh banyaknya lumpur dan sampah daun 
kering serta kayu yang tumbang sehingga terjadi endapan dan pendangkalan pada sepanjang saluran pembuang To'pongo. Panjang saluran pembuang yang di teliti adalah $2236 \mathrm{~m}$. Untuk menganalisis saluran pembuang To'Pongo Desa To'Pongo Kecamatan Lamasi ini dilakukan pengukuran eksisting pada setiap penampang saluran yang berbeda.

Untuk hasil analisa telah didapatkan hasil:(1)Panjang saluran pembuang To'Pongo $=2236 \mathrm{~m},(2)$ Volume eksisting pembuang To'Pongo $=3939.71 \mathrm{~m}^{3}$, (3) Volume rencana $=5781.33 \mathrm{~m}^{3},(4)$ Volume luapan areal $\mathrm{sawah}=406.187 \mathrm{~m}^{3}$, dan (5) Volume saluran tersier $=187.31 \mathrm{~m}^{3}$

Berdasarkan hasil perhitungan di atas, pengoptimalan pada saluran pembuang To'Pongo dengan jumlah volume luapan pada areal sawah adalah $406,187 \mathrm{~m}^{3}$. Sedangkan volume rencana optimalisasi adalah $5781.33 \mathrm{~m}^{3}+3939.71 \mathrm{~m}^{3}=9720,95$ $\mathrm{m}^{3}$. Dengan didukung dengan hasil optimalisasi yang maksimal tentu kecepatan aliran luapan di areal sawah akan semakin maksimal.

\section{KESIMPULAN}

Berdasarkan analisis dan pembahasan yang telah dilakukan maka dapat diambil kesimpulan sebagai berikut:

a) Dengan optimlisasi saluran pembuang To'Pongo dengan Volume rencana 5781,33 $\mathrm{m}^{3}$, luapan banjir di areal persawahan Desa To'Pongo. yang terjadi setiap musim hujan tidak terjadi lagi sehingga petani biasa bercocok tanam dan panen tepat waktu, dengan demikian harapan perekonomian petani akan membaik,

b) Dari hasil pengukuran luas penampang dan kecepatan aliran saluran pembuang To'pongo maka didapatlah dimensi eksisting dengan volume $3939,71 \mathrm{~m}^{3}$, debit(Q) Rata-rata 2,05 m³ detik dan perencanaa optimalisasi adalah $5781,33 \mathrm{~m}^{3}$, debit (Q) $0.32 \mathrm{~m}^{3} /$ detik, Sehingga daya tampung luapan sekarang adalah 3939,71 + $5781,33=9720,95 \mathrm{~m}^{3}$ dengan debit rencana rata-rata $0,32 \mathrm{~m}^{3} /$ detik.

\section{DAFTAR PUSTAKA}

Ajeng, N.S.A. (2006). Penentuan Tarif Irigasi Sebagai Upaya Peningkatan Efisiensi Penggunaan Air Pada Usahatani Padi Sawah. Bogor: Institut Pertanian Bogor.

Anonim. (2013). Kriteria Perencanaan Irigasi KP.- 01. Jakarta: Badan Penerbit Pekerjaan Umum.

Anonim. (2016). Buku Inventarisasi Jaringan Irigasi. UPTD Rantau Fajar Daerah Irigasi Punggur Utara. Provinsi Lampung. 38 hal. Tidak Dipublikasi.

Anonim. (2017). Buku Pintar Operasional Irigasi. UPTD Rukti Endah Daerah Irigasi Punggur Utara. Provinsi Lampung. 56 hal. Tidak Dipublikasi.

Binilang, A. (2014). Perilaku Hubungan Antar Parameter Hidrolis Air Loncat Melalui Pintu Sorong Pada Saluran Terbuka. Jurnal Ilmiah Media Engineering, 4(1), 41-44.

Hariany, S. (2011). Evaluasi Kinerja Jaringan Irigasi Di Saluran Sekunder Pada Berbagai Tingkat Pemberian Air Di Pintu Ukur. Jurnal Rekayasa Vol 15 No.3, Universitas Lampung.

Johansson, R.C. (2000). Pricing Irrigation Water: A literature survei. Washington DC: The Word Bank.

Nurrochmad, F. (2007). Analisis Kinerja Jaringan Irigasi. Yogyakarta: Universitas Gajah Mada. 
Pemerintah Republik Indonesia. (2007). Peraturan Menteri Pekerjaan Umum Nomor 32/PRT/M/2007 tentang Pedoman Operasi dan Pemeliharaan Jaringan Irigasi. Jakarta: Pemerintah Republik Indonesia.

Rosadi, R.A.B. (2015). Dasar-Dasar Teknik Irigasi. Yogyakarta: Graha Ilmu:

Soewarno. (1991). Hidrologi Pengukuran dan Pengolahan Data Aliran Sungai (Hidrometri). Bandung: Nova.

Suroso, Nugroho, P.S., dan Pamuji, P. (2007). Evaluasi Kinerja Jaringan Irigasi Banjaran Untuk Meningkatan Efektifitas Dan Efisiensi Pengelolaan Air Irigasi. Jurnal Dinamika Teknik Sipil Volume 7 No. 1: 55-62.

Suyono, S.,Takeda, K. (1978). Hidrologi Untuk Pengairan. Jakarta: Pradnya Paramita. 
PENA TEKNIK: Jurnal Ilmiah Ilmu-Ilmu Teknik

Volume 3, Nomor 2, September 2018 : 117 - 126

Halaman ini sengaja dikosongkan 